University of Nebraska - Lincoln

DigitalCommons@University of Nebraska - Lincoln

\title{
Comparison of Runoff, Soil Erosion, and Winter Wheat Yields from No-Till and Inversion Tillage Production Systems in Northeastern Oregon
}

\author{
J.D. Williams \\ Columbia Plateau Conservation Research Center, USDA Agricultural Research Service, Pendleton, Oregon \\ H. T. Gollany \\ Columbia Plateau Conservation Research Center, USDA Agricultural Research Service, Pendleton, Oregon, \\ hero.gollany@ars.usda.gov
}

M.C. Siemens

University of Arizona

\section{S.B. Wuest}

Columbia Plateau Conservation Research Center, USDA Agricultural Research Service, Pendleton, Oregon

D. S. Long

Columbia Plateau Conservation Research Center, USDA Agricultural Research Service, Pendleton, Oregon, dan.long@ars.usda.gov

Follow this and additional works at: https://digitalcommons.unl.edu/usdaarsfacpub

Part of the Agricultural Science Commons

Williams, J.D.; Gollany, H. T.; Siemens, M.C.; Wuest, S.B.; and Long, D. S., "Comparison of Runoff, Soil Erosion, and Winter Wheat Yields from No-Till and Inversion Tillage Production Systems in Northeastern Oregon" (2009). Publications from USDA-ARS / UNL Faculty. 267.

https://digitalcommons.unl.edu/usdaarsfacpub/267

This Article is brought to you for free and open access by the U.S. Department of Agriculture: Agricultural Research Service, Lincoln, Nebraska at DigitalCommons@University of Nebraska - Lincoln. It has been accepted for inclusion in Publications from USDA-ARS / UNL Faculty by an authorized administrator of DigitalCommons@University of Nebraska - Lincoln. 


\title{
Comparison of runoff, soil erosion, and winter wheat yields from no-till and inversion tillage production systems in northeastern Oregon
}

\author{
J.D. Williams, H.T. Gollany, M.C. Siemens, S.B. Wuest, and D.S. Long
}

\begin{abstract}
Conservation tillage systems that reduce soil erosion and maintain or increase soil carbon offer long-term benefits for producers in the inland Pacific Northwestern United States but could result in reduced grain yields due to increased pressure from weeds, disease, and insect pests. Our objective was to compare runoff, soil erosion, and crop yields from a conventional tillage, wheat-fallow two-year rotation and a no-till four-year rotation. The experiment was undertaken within a small watershed to provide results that would be representative of conservation effectiveness at the field scale. Two neighboring drainages, 5.8 and

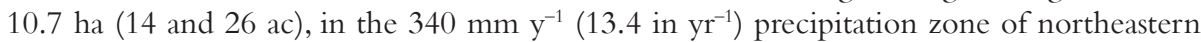
Oregon, were instrumented to record rainfall, runoff, and erosion over a four-year period (2001 through 2004). One drainage was cropped to a winter wheat-fallow rotation and received inversion tillage (tillage fallow). The second drainage was cropped in a four-year no-till rotation: winter wheat-chemical fallow-winter wheat-chickpea (no-till fallow). We recorded 13 runoff events from the inversion tillage system and 3 from the no-till system. Total runoff and erosion values from inversion tillage drainage were $5.1 \mathrm{~mm}(0.20 \mathrm{in})$ and $0.42 \mathrm{Mg} \mathrm{ha}^{-1}\left(0.19 \mathrm{tn} \mathrm{ac} c^{-1}\right)$ versus $0.7 \mathrm{~mm}(0.03 \mathrm{in})$ and $0.01 \mathrm{Mg} \mathrm{ha}^{-1}\left(<0.005 \mathrm{tn} \mathrm{ac}^{-1}\right)$ from no-till drainage. The no-till rotation was substantially more effective in conserving soil and water in this field-scale comparison. Soil erosion observed in this research is a fraction of that reported for similar tillage practices outside of the Pacific Northwestern. Mean wheat yields did not significantly differ between inversion tillage and no-till treatments despite intensifying the rotation by replacing one year of fallow with a chickpea crop in the four-year rotation. Because of high year-to-year variability in yield and limited sample size, more study is needed to compare winter wheat yields in no-till production systems with inversion tillage. The no-till cropping system was more effective in reducing runoff and soil erosion and provides producers with an ability to protect soil and water resources in the dryland Pacific Northwest.
\end{abstract}

Key words: conservation assessment—crop rotation-direct seeding-field scale-Pacific Northwest-small grain production-watershed

\begin{abstract}
More than 900,000 ha (2.2 million ac) are planted to winter wheat following fallow each year in the interior Pacific Northwest (PNW), United States (Smiley 1992). Soil erosion in this system has been recognized since 1909 (McGregor 1982). Average soil loss rates range from 3 to $50 \mathrm{Mg}$ of soil $\mathrm{ha}^{-1} \mathrm{y}^{-1}$ (1.3 to $22.3 \mathrm{tn} \mathrm{ac}^{-1} \mathrm{yr}^{-1}$ ) (Zuzel et al. 1982; Nagle and Ritchie 2004) and exceed the established USDA soil loss tolerance limits of 2.2 to $11.2 \mathrm{Mg} \mathrm{ha}^{-1} \mathrm{y}^{-1}$ (1.0 to $5.0 \mathrm{tn}$
\end{abstract}

by $40 \%$ to $80 \%$ in the presence of 1 to $2 \mathrm{Mg}$ $\mathrm{ha}^{-1}\left(0.5\right.$ to $\left.0.9 \mathrm{tn} \mathrm{ac}{ }^{-1}\right)$ of crop residue compared to bare soil (McCool et al. 1995).

No-till is a conservation tillage practice that, in addition to leaving considerable residue on the soil surface, leaves the soil undisturbed from harvest to planting, which promotes well formed soil macroaggregates (Cambardella and Elliott 1993) that result in increased infiltration, less runoff, and less soil movement. Six et al. (2000) reported that formation of new microaggregates within macroaggregates was doubled in no-till compared to inversion tillage. In southeastern Australia, saturated hydraulic conductivity $(K)$ was eight times greater in grey clay soils and two times greater in sandy loam soils in a no-till wheat system than $K$ in an inversion tillage system (Bissett and O'Leary 1996). Soil erosion from no-till corn silage and grain was less than that from inversion tillage treatments in southern Mississippi (McGregor and Greer 1982).

Similar soil loss and runoff results have been obtained from a variety of crops in plot research in Nebraska (Dickey et al. 1984), field research in Maryland (Angle et al. 1984), plot, field, and watershed research in Brazil (Castro et al. 1999), and research conducted in the North Appalachian Experimental Watershed in Ohio (Edwards et al. 1993; Shipitalo and Edwards 1998). No-till research in the dryland region of the PNW has been limited to small plot experiments where the runoff occurred only in conjunction with frozen soil (Khalid and Chen 2003). We found no other reports in the literature from the PNW where no-till and its soil conservation effects were investigated at the field scale using drainages or small watersheds.

The objectives of this study were to compare a conventional, intensively tilled winter wheat-fallow system versus a no-till fouryear cropping rotation system in terms of runoff, soil erosion, and crop yields. The results presented here emphasize runoff, soil erosion, and cropping system productivity

John D. Williams is a hydrologist, Hero T. Gollany is a soil scientist, Stewart B. Wuest is a soil scientist, and Daniel S. Long is an agronomist at the Columbia Plateau Conservation Research Center, USDA Agricultural Research Service, Pendleton, Oregon. Mark C. Siemens is an agricultural engineer with University of Arizona, Yuma, Arizona. 
across a drainage typical of the steep rolling terrain found within the inland PNW.

\section{Materials and Methods}

Site Description. The research began in October 2000 and was conducted for four years within two small neighboring ephemeral drainages in the Wildhorse Creek watershed $\left(45^{\circ} 49^{\prime} 0.43^{\prime \prime} \mathrm{N}, 118^{\circ} 38^{\prime} 35.46^{\prime \prime W}\right)$ in northeastern Oregon (figure 1). The drainages, one first-order and one zero-order (Fritz et al. 2006), were instrumented to record runoff and erosion. Drainage areas, slopes, and relief ratios were determined by analysis of a subdecimeter digital elevation model generated from data collected using a Trimble model 4600 GPS total-station (table 1). The soils were well drained Walla Walla silt loams (coarse-silty, mixed, superactive, mesic Typic Haploxerolls-United States; Kastanozems-Food and Agriculture Organization). Soil development occurred within a mantle of loess derived from Pleistocene aeolian deposits onto basalt flows of the Miocene Epoch (Johnson and Makinson 1988). Percent ground cover consisting of current year's growth and previous year residue was measured in late November of 2002, 2003, and 2004 using a digital adaptation of the cross-hair frame method developed by Floyd and Anderson (1982).

Meteorological records dating from 1931 at the USDA Columbia Plateau Conservation Research Center and Oregon State University Columbia Basin Agricultural Research Center), 11 km (6.8 mi) south of the research site, were compared to weather data recorded during the study. These long-term records show minimum and maximum air temperatures of $-34^{\circ} \mathrm{C}$ and $46^{\circ} \mathrm{C}\left(-29^{\circ} \mathrm{F}\right.$ and $\left.115^{\circ} \mathrm{F}\right)$, with a 71-year average mean annual temperature of $11^{\circ} \mathrm{C}\left(52^{\circ} \mathrm{F}\right)$. Frost-free days range from 135 to 170 (Johnson and Makinson 1988). Approximately $70 \%$ of precipitation occurs between November and April from maritime fronts that produce low intensity storms averaging $0.5 \mathrm{~mm} \mathrm{~h}^{-1}$ (0.02 in $\left.\mathrm{hr}^{-1}\right)$, equivalent to accumulations of 1.5 $\mathrm{mm}$ (0.06 in) over 3 hours (Brown et al. 1983). Long-term annual precipitation averages $422 \mathrm{~mm}$ (16.61 in). Snow cover is transient, with accumulated snow subject to rapid melting by frequent warm fronts. Soil erosion in the PNW occurs predominately from January through March (Zuzel et al. 1982, 1986).

\section{Figure 1}

Location of paired drainage research sites within Wildhorse Creek watershed in northeastern Oregon.

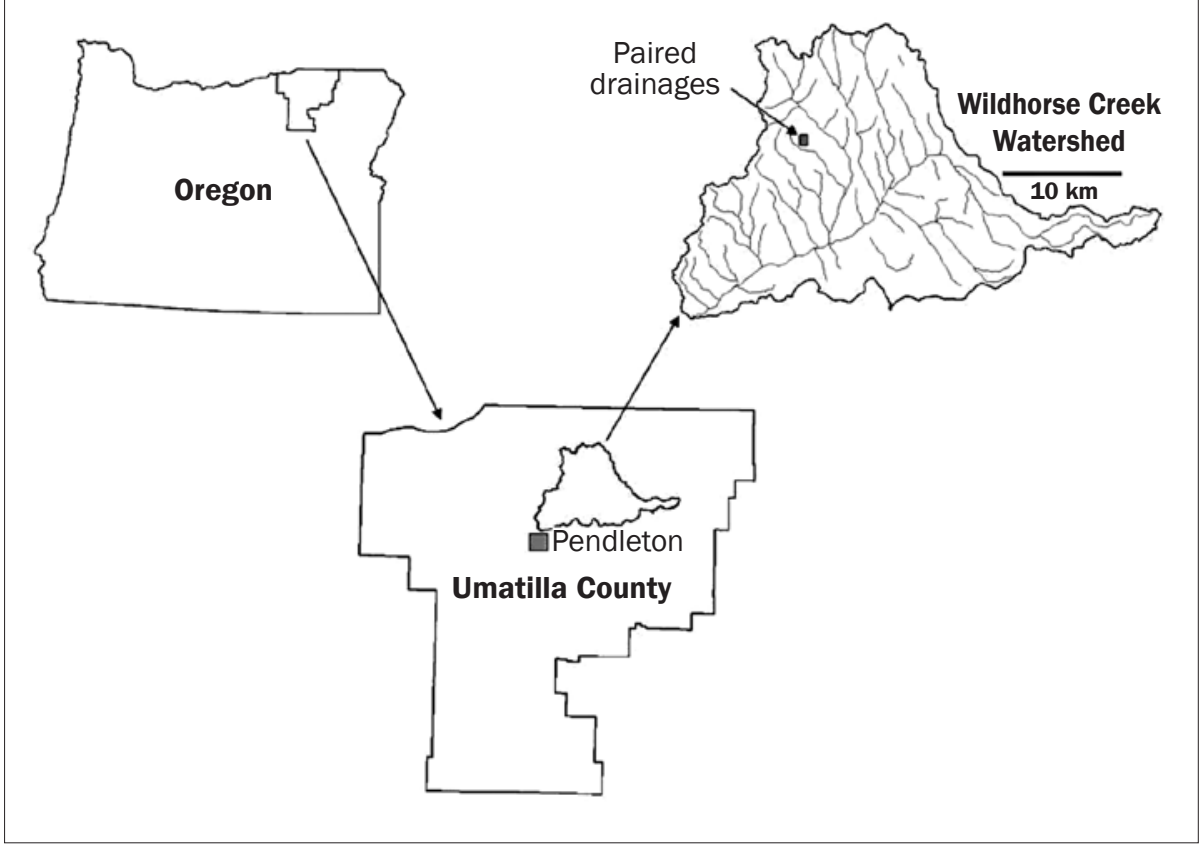

Table 1

Description of drainages used for comparison of conservation and production responses to notill and inversion tillage practices.

\begin{tabular}{llllll}
\hline Drainage & Area $(\mathrm{ha})$ & $\boldsymbol{R}_{\boldsymbol{r}}{ }^{*}$ & Elevation at flume $(\mathbf{m})$ & Maximum slope & Aspect \\
\hline No-till & 10.7 & 0.05 & 535 & $30 \%$ & Southeast \\
Inversion tillage & 5.8 & 0.08 & 540 & $20 \%$ & East \\
\hline
\end{tabular}

${ }^{*} R_{r}=$ Relief ratio defined as $\mathrm{R} / \mathrm{L}$, where $R$ is the elevation difference between outlet at the flume and headwater divide, and $L$ is the maximum length of the basin measured in the same units as $R$ along a line parallel to the main channel.

Cultural Practices and Field Plots. The first-order drainage was evenly divided into four plots to accommodate all phases of a four-year rotation (figure 2). Each phase of the rotation, winter wheat (Triticum aestivum L.)-chemical fallow-winter wheat-chickpea (Cicer arietinum L.), was represented each year in the drainage, with each of the plots cycling through the rotation in the four years of study (table 2). Crops were simultaneously seeded and fertilized using a hoe-type, notill drill on $305 \mathrm{~mm}$ (12 in) centers. The zero-order drainage was farmed using conventional inversion tillage to produce winter wheat in a two-year, crop-fallow rotation. Primary tillage was with a moldboard plow. Secondary tillage consisted of cultivation, injection fertilization, and two to three passes through the field with a rodweeder. The conventionally tilled crop was seeded with a double-disc-opener drill on 203-mm (8-in) centers. Fertilizer was applied in May preceding the fall planting of wheat in the inversion tillage drainage. Crop yield data were based on commercial combine truckscale weights.

Monitoring and Sampling Procedures. A meteorological station located on the divide between the two drainages recorded precipitation, air temperature, soil temperature at $25-\mathrm{mm}$ (1-in) and 50-mm (2-in) depths, wind speed and direction, solar radiation, and relative humidity (Oviatt and Wilkins 2002).

In crop years 2003 and 2004, six metal runoff collectors were placed on backslope positions in each watershed during the typical erosion season (November through March) for this region (figure 2). The metal frames consisted of a 9.5-mm (0.374-in) thick by $254-\mathrm{mm}$ (10-in) wide steel plate bent into a rectangle about $800-\mathrm{mm}$ (31-in) wide and 1,200-mm (47-in) long, with the 


\section{Figure 2}

Plot layout and topography of paired drainages in the Wildhorse Creek watershed, northeastern Oregon.

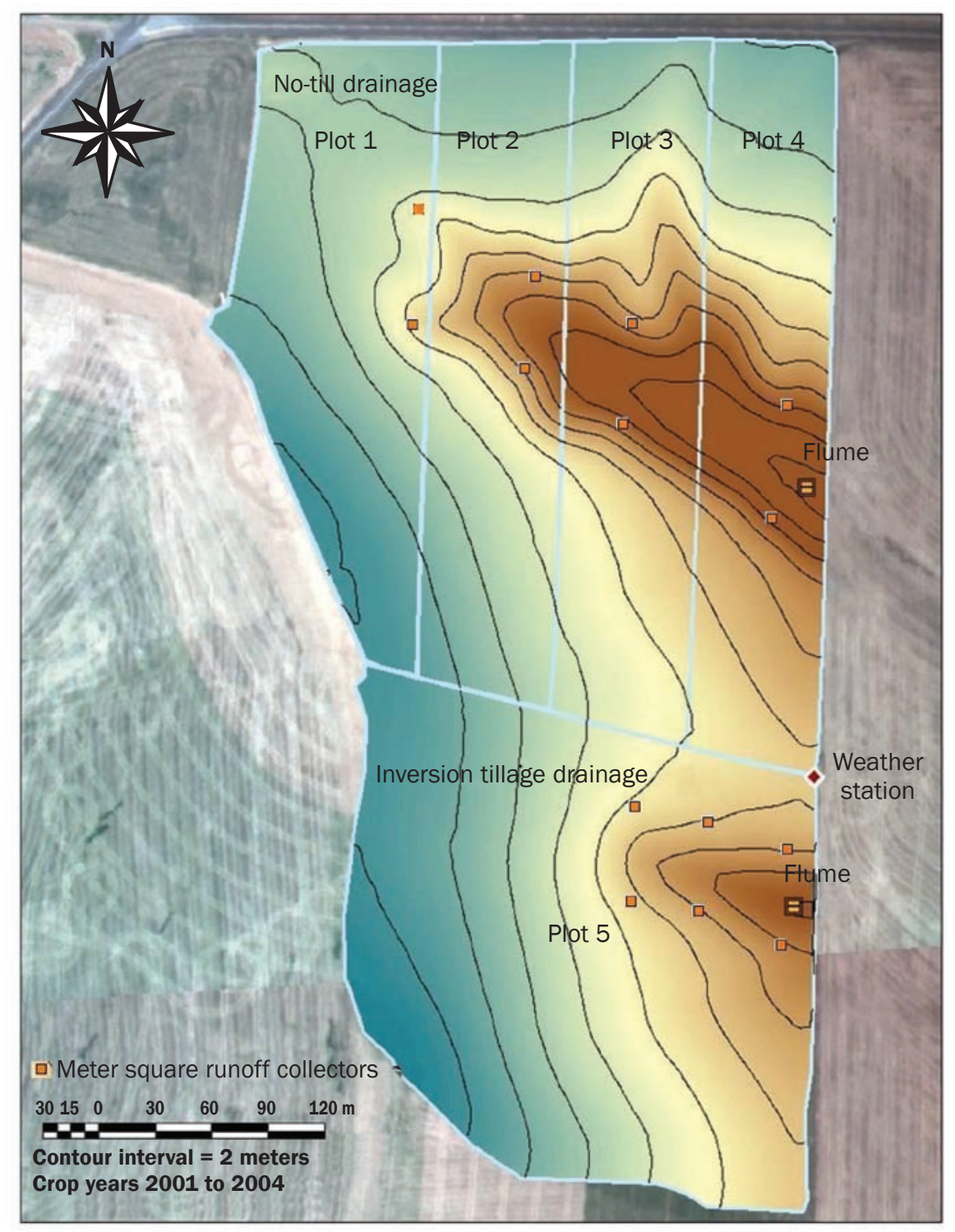

Note: Color gradient is a visual aid to demonstrate elevation change at the research site.

\section{Table 2}

Rotation assigned to no-till and inversion tillage drainages for crop years 2001 through 2004 .

\begin{tabular}{llllllll}
\hline \multirow{2}{*}{ Year } & No-till & & & & & \multicolumn{2}{c}{ Inversion tillage } \\
\hline & Plot 1 & Plot 2 & Plot 3 & & & Plot 4 & Plot 5 \\
\hline 2001 & CP* & CF & SW & & WW & F \\
2002 & WW & WW & CF & & CP & WW \\
2003 & CF & CP & WW & & WW & F \\
2004 & WW & WW & CP & & CF & WW \\
\hline
\end{tabular}

Notes: $\mathrm{CP}=$ chickpea. $\mathrm{CF}=$ chemical fallow. $\mathrm{F}=$ fallow (inversion tillage). $\mathrm{SW}=$ spring wheat. $\mathrm{WW}=$ winter wheat. bottom side formed into a slight V-shaped funnel. The total surface area circumscribed by the frame was $1 \mathrm{~m}^{2}\left(11 \mathrm{ft}^{2}\right)$. The frame was placed with the funnel pointing downslope, and the entire frame was pounded into the ground using sledge hammers or post-driving equipment. The soil immediately inside the frame was tamped to seal the soil surface to the frame and prevent leakage. A hose attached to a tube at the bottom of the funnel led to a 20-L (5-gal) container on the slope below the frame. The containers were checked periodically, and runoff was collected after multiple events to avoid overflow. Total annual runoff and eroded material were determined by weighing, drying, and reweighing material collected in the containers.

At the mouth of each drainage, runoff was measured with 23-cm (9-in) Parshall flumes (figure 2). Flow stage was recorded using ultrasonic distance sensors, and flow rate was calculated using a standard rating curve (US Department of the Interior 2006). Runoff samples were collected using flowactivated, commercial storm water samplers using a liquid level switch at a stage of $1 \mathrm{~cm}$ (0.4 in) or greater. Samples (0.5 L [0.1 gal]) were collected every 40 minutes for up to eight hours of continuous runoff. Samples were analyzed for suspended sediment concentrations (Glysson and Grays 2002). Bedwash traps (188 L [49.8 gal] plastic livestock water trough, approximately $1.5-\mathrm{m}$ [4.9-ft] wide $\times 0.5-\mathrm{m}[1.6-\mathrm{ft}]$ long $\times 0.3-\mathrm{m}$ [1.0-ft] deep and covered with a slatted top) were installed immediately upstream from the flumes. After each runoff event, the entire volume of bedwash and water was collected, the bedwash material was allowed to settle, and the water was decanted. Subsamples of the settled material were dried and weighed to determine bulk density. The bulk density was applied to the original volume of bedwash to determine its mass. Event values for eroded material are the total of suspended sediment concentrations plus the weight of the bed wash.

A Case IH 1470 rotary combine equipped with a $7.6-\mathrm{m}(25-\mathrm{ft})$ header was used to harvest the crops. Grain weights were obtained by using certified truck scales at time of delivery to the local country elevator. Crop yields from the first year in the rotation (2001) were excluded from the analysis because they immediately followed the 2000 mustard (Sinapis alba) crop, thus 


\section{Figure 3}

Seasonal mean air temperature and precipitation during 2001 to 2004 in context of 71 years of records.
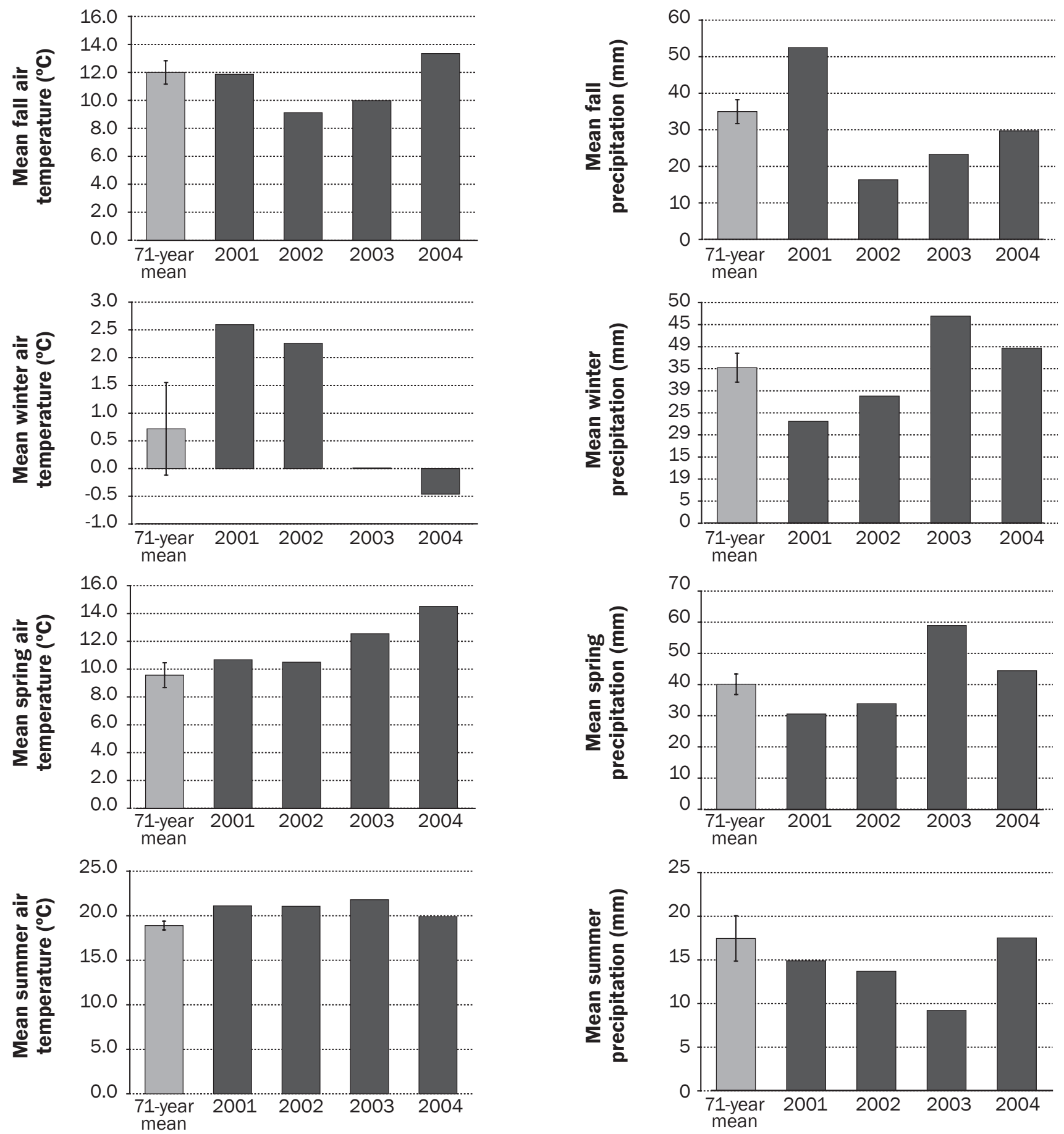

Note: Means of daily values for each season (winter = January to March; spring = April to June; summer = July to September; fall = October to December) and long-term 95\% confidence intervals are shown.

creating a recrop condition in treatments that were intended as winter wheat following chemical fallow and winter wheat after chickpeas.
Experimental Design and Statistical Procedures. This study was designed as a field-scale, eight-year, side-by-side, spatially unreplicated comparison of two crop production systems in adjoining headwater drainages. The results reported here are from the first complete four-year rotation. The experimental units are the drainages. All 


\section{Figure 4}

Mean and standard error values for crop residue.

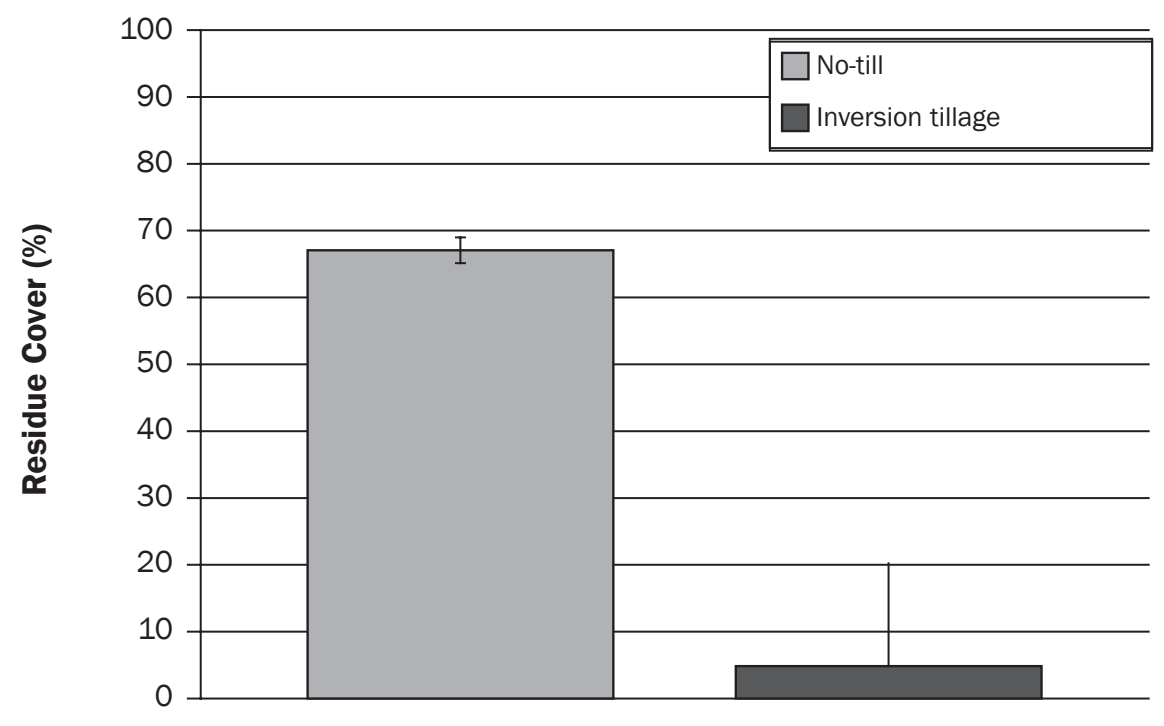

statistical tests were conducted at $p<0.05$. With acknowledgement of pseudoreplication (Hurlbert 1984), data were analyzed using paired " $t$ " tests (Microsoft Office Excel 2003) and PROC GLM in SAS (SAS Institute, Cary, North Carolina). Annual values from $1 \mathrm{~m}^{2}\left(3 \mathrm{ft}^{2}\right)$ plots for 2003 and $2004(n=2)$ and individual event runoff $(n=11)$ and soil erosion $(n=10)$ data were obtained using paired " $t$ " tests to demonstrate treatment differences. Difference in treatment means for winter wheat yields from 2002, 2003, and $2004(n=3)$ were analyzed using PROC GLM. Crop yield data from 2001 were not used in the analysis to eliminate confounding factors associated with a previous research project conducted at the site. Drainage and $1 \mathrm{~m}^{2}$ plot runoff data were standardized as a ratio of runoff to precipitation ( $\mathrm{R}: \mathrm{P}$ ratios) during November through March, when the $1 \mathrm{~m}^{2}$ plots were in place, for comparative discussion with no-till responses in dissimilar climates.

\section{Results and Discussion}

Meteorological and Soil Surface Conditions. Large soil losses in this region typically result from hydrologic processes involving either rain on frozen soil, with or without snow cover, or rain on snow-covered unfrozen soil. These events occur from one to five times each year (Zuzel et al. 1986). Additionally, tilled, unprotected soil moves downslope in the absence of rainfall when the top 3 to 4 $\mathrm{cm}$ (1.2 to $1.6 \mathrm{in})$ of soil thaws and becomes a viscous, flowing slurry (Zuzel and Pikul
1987). Compared with long-term Columbia Plateau Conservation Research Center and Oregon State University Columbia Basin Agricultural Research Center data, weather conditions were abnormally warm and dry during much of the erosion season (January through March) in 2001 and 2002 and were wetter than normal during 2003 (figure 3). Conditions of continuous deep frozen soil or frequent freeze-thaw cycles did not occur at any time during 2001 through 2004.

Residue cover was significantly $(p=0.05)$ greater in the no-till (67\%) than in the inversion-tillage (5\%) plots (figure 4). In 2003, the inversion-tillage drainage was fall burned and moldboard plowed, leaving a bare but rough surface that provided abundant detention storage. Inversion tillage with residue burning is a common practice in the PNW region to control weeds, especially downy brome (Bromus tectorum). In 2004, the inversion-tillage drainage was cultivated once, fertilized, and rod-weeded twice before fall seeding.

1-m² Plot Runoff and Soil Erosion. The inversion-tillage system produced significantly $(p \leq 0.05)$ more runoff (3.5 times) and eroded material (52 times) than the no-till production system (figure 5 ). The greater eroded material under the inversion-tillage system was due to significantly less cover after the residue was burned and the soil was plowed in the fall of 2002 (figure 4). Zuzel and Pikul (1993) reported that percentage of straw cover and normalized soil loss were highly correlated $(r=0.99)$ in a study in northeastern Oregon.
Drainage Runoff and Soil Erosion. Thirteen runoff and soil erosion events occurred during 2001 to 2004 (table 3). Soil erosion data from four events and runoff data from two events were not collected because of equipment failure. We were able to obtain a partial measure of eroded material for one of these events (January 31, 2003) by relying on the material collected in the partially filled bedwash trap. Although we were able to collect stage data for events on April 15, 2004 and June 8, 2004, we felt it is inappropriate to use these values in our analysis because the trap overfilled with eroded material. Photographic records of one of the second missed snow melt events (January 23, 2004), where sediment-sampling equipment failure occurred in conjunction with frozen soil, show relatively clear water running from under the snow through the flume, suggesting the amount of soil lost during that event was negligible. The events from which we lost data were not unusual; based on records at Oregon State University Columbia Basin Agricultural Research Center and Columbia Plateau Conservation Research Center, daily rainfall return periods (the expected frequency of a storm of a given size occurring), were one year for the two events occurring in January 2003 and 2004 when runoff and erosion data were lost, and 1.8 years and 1.6 years for events in April and June 2004 when erosion data were lost. Because of these missed events, the annual soil loss values reported here are conservative.

Four-year runoff and soil erosion values at the drainage scale were significantly less in the no-till system (figure 6) compared to the inversion tillage system, where 3.4 times more runoff (79 $\mathrm{mm}$ [3.1 in] versus $23 \mathrm{~mm}$ [0.9 in]) and 52 times more eroded material (11.01 $\mathrm{Mg} \mathrm{ha}^{-1}\left[4.91 \mathrm{tn} \mathrm{ac}^{-1}\right]$ versus $0.21 \mathrm{Mg}$ $\left.\mathrm{ha}^{-1}\left[0.09 \mathrm{tn} \mathrm{ac}^{-1}\right]\right)$ were produced than in the no-till system. Our results are corroborated by results from two sites within $10 \mathrm{~km}$ (6.2 mi) of this research site that effectively bracket the size and slope conditions of the research site reported here. Runoff and soil erosion were monitored through the same set of weather events at a $1.5 \mathrm{ha}(3.7 \mathrm{ac})$ hillslope (23\% slope) and a second paired drainage (18 ha and 25 ha [ $44.5 \mathrm{ac}$ and $61.8 \mathrm{ac}]$ ). Both sites were managed as no-till systems, and neither runoff nor erosion was observed during crop years 2001 to 2004. Prior to beginning these studies, both sites had a long history (100 years) of winter wheat-summer fallow man- 
aged with inversion tillage, which resulted in severe soil erosion that is physically visible in the form of a small gully adjacent to the hillslope site.

None of the four runoff and soil erosion events recorded in the no-till drainage occurred as the result of rainfall on frozen soil or exceptionally long storms (table 3 ). The maximum rainfall intensity on January 31,2003 , was higher than the mean intensity for all runoff events, but there were three higher intensity storms that did not generate runoff in the no-till drainage (table 3). Otherwise, there was nothing unusual about the weather associated with these events. There was sufficient ground cover in the plot nearest the flume (number 4) in the no-till drainage in 2003 and 2004 to limit runoff and soil erosion; residue cover was $64 \%$ in the wheat following chickpeas crop (2003) and over 95\% in the chemical fallow in 2004 (table 2). While we cannot eliminate the crop rotations in 2003 and 2004 as the causal factors for runoff that occurred in plot number 4 , it is just as likely the runoff, if it came entirely from this plot, was the result of activities associated with the installation of the flume and sediment-sampling equipment. In the inversion-till drainage, however, we have photographic evidence of runoff and rill formation well into the upper part of the drainage.

January through February in 2001 and December through May in 2002 were drier than normal (figure 3), which apparently accounted for the lack of runoff during these years. As we noted previously, conditions typically associated with large erosion events in this region did not develop. Soil loss values were well below the expected range of 3 to $50 \mathrm{Mg} \mathrm{ha}^{-1} \mathrm{y}^{-1}\left(22.3 \mathrm{tn}^{-1} \mathrm{yr}^{-1}\right)$ reported by Zuzel et al. (1982). Three events occurred with rainfall on snow covered, patchily frozen soil, but the total accumulated soil loss during these three days amounted to less than the fourth largest event recorded during 2001 through 2004. The four largest erosion events occurred with rain on unfrozen soils at moderate rainfall intensity and accumulation. The largest of these events, on February 16,2004 , resulted from a storm with a mean rainfall intensity of $1.7 \mathrm{~mm} \mathrm{~h}^{-1}\left(0.08 \mathrm{in} \mathrm{hr}^{-1}\right)$ and accumulation of $11.7 \mathrm{~mm}$ (0.46 in), and the smallest event occurred on February 24, 2004 , with an mean intensity of $4.1 \mathrm{~mm} \mathrm{~h}^{-1}$ $\left(0.11 \mathrm{in} \mathrm{hr}^{-1}\right)$ and accumulation of $9.2 \mathrm{~mm}$ (0.36 in).

\section{Figure 5}

Mean and standard error values for (a) runoff and (b) eroded materials collected from $1 \mathrm{~m}^{2}$ plots during crop year 2003 and $2004(n=2)$.

(a)

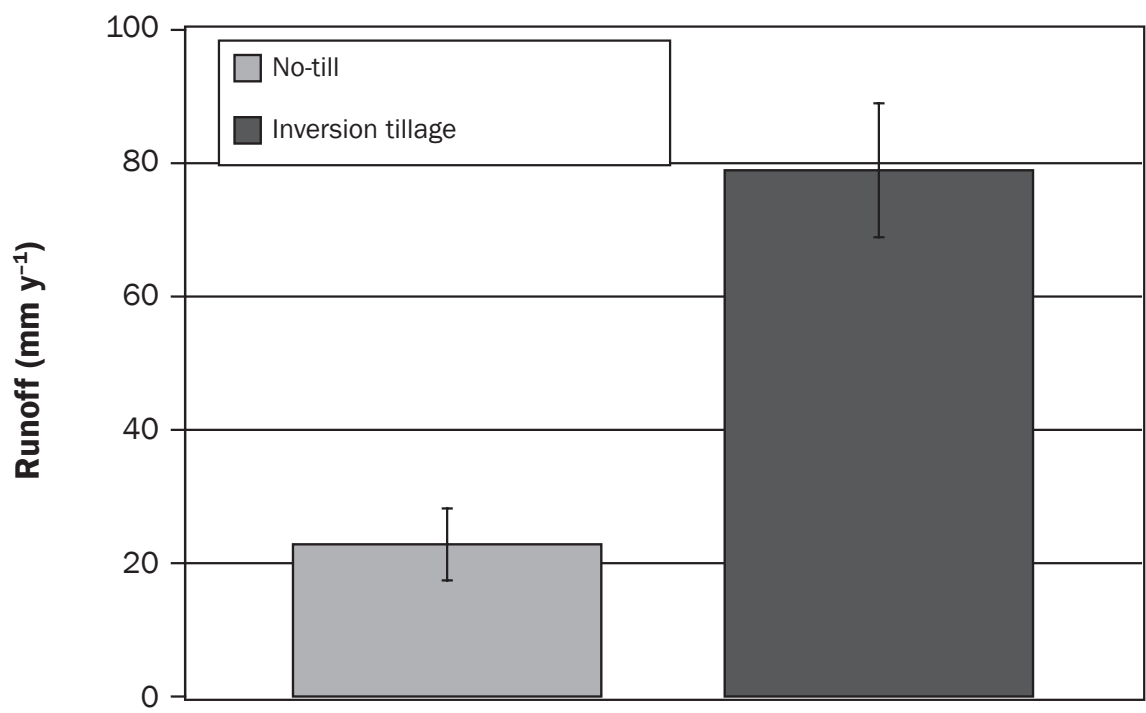

(b)

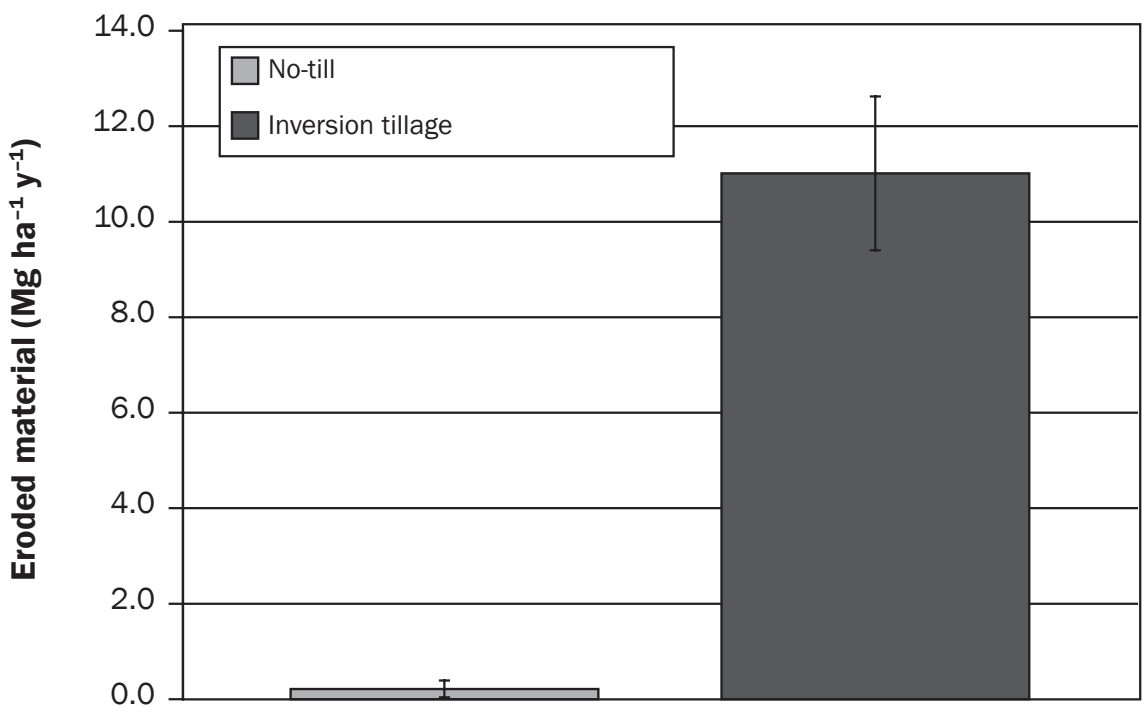

Hydrologic Response of 1-m Collectors Versus Entire Drainage. Measured in flumes at the mouth of either drainage, the average runoff from the inversion tillage drainage in 2003 through 2004 was $3 \mathrm{~mm}$ (0.10 in), or $1 \%$ of the erosion season precipitation (264 mm [10.39 in]) for this year. In contrast, hillslope runoff, measured in $1-\mathrm{m}^{2}\left(3-\mathrm{ft}^{2}\right)$ collectors, was $79 \mathrm{~mm}$ (3.11 in), or $30 \%$ of the precipitation. The difference between hillslope and drainage runoff leaves $76 \mathrm{~mm}$ (3 in) that apparently infiltrated into the lower slope and drainage bottom before reaching the flume. Assuming a homogeneous distri- bution of precipitation across these drainages, this represents a substantial redistribution of precipitation. With less localized runoff, the no-till system apparently maintained a more homogenous distribution of precipitation across the landscape, resulting in more stored water on hillslopes.

At the field scale, the dominant erosion process in this region is the concentration of runoff on bare soil surfaces and formation of rills (Zuzel et al. 1982). We observed a classic example of this process in the inversion tillage drainage in 2004. Although more suspended sediments were measured in 
Table 3

Runoff and erosion events in no-till and inversion tillage drainages, 2001 through 2004.

\begin{tabular}{|c|c|c|c|c|c|c|c|c|c|}
\hline \multirow[b]{2}{*}{ Date } & \multirow{2}{*}{$\begin{array}{l}\text { Precipitation* } \\
\text { total } \\
(\mathrm{mm})\end{array}$} & \multirow[b]{2}{*}{$\begin{array}{l}\text { Duration } \\
\text { (hr:min) }\end{array}$} & \multirow{2}{*}{$\begin{array}{l}\text { Max. } \\
\text { intensity } \\
\left(\mathrm{mm} \mathrm{h}^{-1}\right)\end{array}$} & \multirow{2}{*}{$\begin{array}{l}\text { Mean } \\
\text { intensity } \\
\left(\mathrm{mm} \mathrm{h}^{-1}\right)\end{array}$} & \multirow[b]{2}{*}{$\begin{array}{l}\text { Event } \\
\text { type } †\end{array}$} & \multicolumn{2}{|c|}{ Inversion tillage } & \multicolumn{2}{|l|}{ No-till } \\
\hline & & & & & & $\begin{array}{l}\text { RO } \\
\text { (mm) }\end{array}$ & $\begin{array}{l}\text { EM } \S \\
\left(M g a^{-1}\right)\end{array}$ & $\begin{array}{l}\text { RO } \\
(\mathrm{mm})\end{array}$ & $\begin{array}{l}\text { EM } \\
\left(M \text { ha }^{-1}\right)\end{array}$ \\
\hline Jan. 26, 2003 & 15.6 & $21: 43$ & 6.2 & 2.1 & NFS & 0.3 & 0.01 & 0.0 & 0.00 \\
\hline Jan. 30, 2003 & 14.6 & $21: 10$ & 7.8 & 2.2 & NFS & 0.5 & 0.07 & 0.2 & $<0.01$ \\
\hline Jan. 31, 2003 & 16.9 & $16: 04$ & 11.8 & 2.5 & NFS & ND & $0.03 \ddagger$ & 0.2 & $<0.01$ \\
\hline Jan. 28, 2004 & 19.5 & $39: 24$ & 11.4 & 2.1 & RS & 0.6 & 0.04 & 0.0 & 0.00 \\
\hline Feb. 6, 2004 & 10.3 & $21: 15$ & 5.0 & 1.7 & NFS & 0.3 & 0.01 & $<0.1$ & 0.00 \\
\hline Feb. 16, 2004 & 11.6 & $10: 13$ & 4.3 & 1.7 & NFS & 0.6 & 0.14 & 0.0 & 0.00 \\
\hline Feb. 17, 2004 & 7.6 & $15: 08$ & 5.5 & 1.8 & NFS & 0.3 & 0.05 & 0.0 & 0.00 \\
\hline Feb. 24, 2004 & 9.2 & $09: 54$ & 17.4 & 4.1 & NFS & 0.3 & 0.05 & 0.0 & 0.00 \\
\hline Apr. 15, 2004 & 24.9 & 08:29 & 14.1 & 4.7 & NFS & 0.3 & ND & 0.0 & 0.00 \\
\hline
\end{tabular}

Notes: ND = not determined, event observed but data were not collected. RO = runoff. EM = eroded material.

* Precipitation intensities are based on tipping bucket, instantaneous values standardized to $\mathrm{mm} \mathrm{h}^{-1}$.

† Storm types: NFS = rain on nonfrozen soil, RS = rain on snow (discontinuous patches of frozen soil).

‡ Estimated from bedwash sample.

Table 4

Comparison of runoff ratios and soil erosion from this study to other reported hydrologic and erosion research.

\begin{tabular}{|c|c|c|c|c|c|c|c|c|c|}
\hline \multirow[b]{2}{*}{ Study } & \multirow{2}{*}{$\begin{array}{l}\text { Location } \\
\text { (state or } \\
\text { province) }\end{array}$} & \multirow{2}{*}{$\begin{array}{l}\text { Study } \\
\text { duration } \\
\text { (years) }\end{array}$} & \multirow{2}{*}{$\begin{array}{l}\text { Cropping } \\
\text { systems }\end{array}$} & \multirow{2}{*}{$\begin{array}{l}\text { Plot or } \\
\text { drainage } \\
\text { area }\end{array}$} & \multirow{2}{*}{$\begin{array}{l}\text { Slope } \\
(\%)\end{array}$} & \multicolumn{2}{|c|}{ Runoff ratio* } & \multicolumn{2}{|c|}{$\begin{array}{l}\text { Soil erosion } \\
\left(\mathrm{Mg} \mathrm{ha}^{-1} \mathrm{y}^{-1}\right)\end{array}$} \\
\hline & & & & & & NT & IT & $\overline{\mathrm{NT}}$ & IT \\
\hline Current study & & 4 & chickpeas & 5.8 to 10.7 ha & 15 to 20 & $<0.01$ & 0.01 & $<0.01$ & 0.11 \\
\hline \multirow[t]{2}{*}{ McGregor and Greer 1982} & Mississippi & 3 & Corn & 0.01 ha & 6 to 7 & 0.26 & 0.31 & 0.77 & 17.54 \\
\hline & & & & 0.5 to 1.0 ha & & 0.32 & 0.25 & 0.48 & 0.86 \\
\hline Angle et al. 1984 & Maryland & 5 & Corn & 0.2 to 0.4 ha & 6 to 7 & 0.01 & 0.03 & 3.33 & 26.22 \\
\hline Shipitalo and Edwards 1998 & Ohio & 28 & $\begin{array}{l}\text { Corn and } \\
\text { soybean }\end{array}$ & 0.5 to 1.0 ha & 7 to 10 & $<0.01$ & 0.16 & 0.01 & 5.34 \\
\hline \multirow[t]{2}{*}{ Castro et al. 1999} & Planalto Médio & 3 & Oats and & $1 \mathrm{~m}^{2}$ & 5 to 9 & 0.06 & 0.16 & 0.2 & 4 \\
\hline & $\begin{array}{l}\text { in Rio Grande } \\
\text { do Sul, Brazil }\end{array}$ & 5 & soybean & 0.01 ha & & 0.5 & 3.1 & 0.4 & 8.5 \\
\hline
\end{tabular}

Notes: $\mathrm{NT}=$ no-till. IT = inversion tillage.

* Runoff ratio $=$ runoff $/$ precipitation. 
the inversion tillage drainage in 2003 than 2004 , less soil erosion was recorded in the $1-\mathrm{m}^{2}\left(3-\mathrm{ft}^{2}\right)$ plots in 2004 than 2003. This inverse relationship resulted from the abundant detention storage at the drainage scale following moldboard plowing in the fall of 2002, which limited soil erosion to very local redistribution and rill development at the drainage bottom. In 2004, after rod-weeding, planting, and weathering reduced the detention roughness, rills developed on the sides of the drainage, which in turn coalesced into a concentrated channel at the drainage bottom. However, we never observed rills in the no-till system.

With few studies conducted under similar weather and soil conditions, comparisons to findings from studies conducted in different environments are useful to gain a sense of relative responses of management practices. In general, soil erosion recorded at the study site was less than that reported elsewhere under different cropping systems and meteorological conditions (table 4). Given that the plots and drainages in this study are on substantially steeper slopes, one would expect greater rates of erosion if the region did not have such low rainfall intensities and small raindrop size (Bubenzer et al. 1985). At the small plot scale, we recorded $0.21 \mathrm{Mg} \mathrm{ha}^{-1}$ $\mathrm{y}^{-1}\left(0.09 \mathrm{tn} \mathrm{ac}^{-1} \mathrm{yr}^{-1}\right)$ in the no-till and 11.01 $\mathrm{Mg} \mathrm{ha}^{-1} \mathrm{y}^{-1}\left(4.91 \mathrm{tn} \mathrm{ac}^{-1} \mathrm{yr}^{-1}\right)$ in the inversion tillage systems, which are within the range reported in the other studies. Interestingly, the other study from the PNW (Khalid and Chen 2003) reported a no-till value similar to our results at the $1 \mathrm{~m}^{2}\left(3-\mathrm{ft}^{2}\right)$ scale. A relatively larger value for the inversion tillage in this study than reported by Khalid and Chen (2003) was likely the result of slope; whereas we installed our $1 \mathrm{~m}^{2}$ plots on steep drainage backslope positions, Khalid and Chen's plots were at shallower shoulder-slope positions. All of the other studies reviewed here were conducted under substantially different climatic conditions. Values reported from $1 \mathrm{~m}^{2}$ plots by Castro et al. (1999) are also within a factor of two of our values, but their larger scale values for no-till are more similar to those reported for larger scale studies from other high rainfall regions. Two exceptions of greater runoff to precipitation ratios in no-till occurred where no-till practices had created smooth surfaces without the detention storage necessary to capture spring and summer rainfall (McGregor and Greer 1982; Edwards et al. 1993). Despite the differences

\section{Figure 6}

Mean and standard error values for (a) runoff and (b) eroded material recorded for flumes at the bottoms of drainages managed either as no-till or inversion tillage systems during crop years 2001 through $2004(n=4)$.

(a)

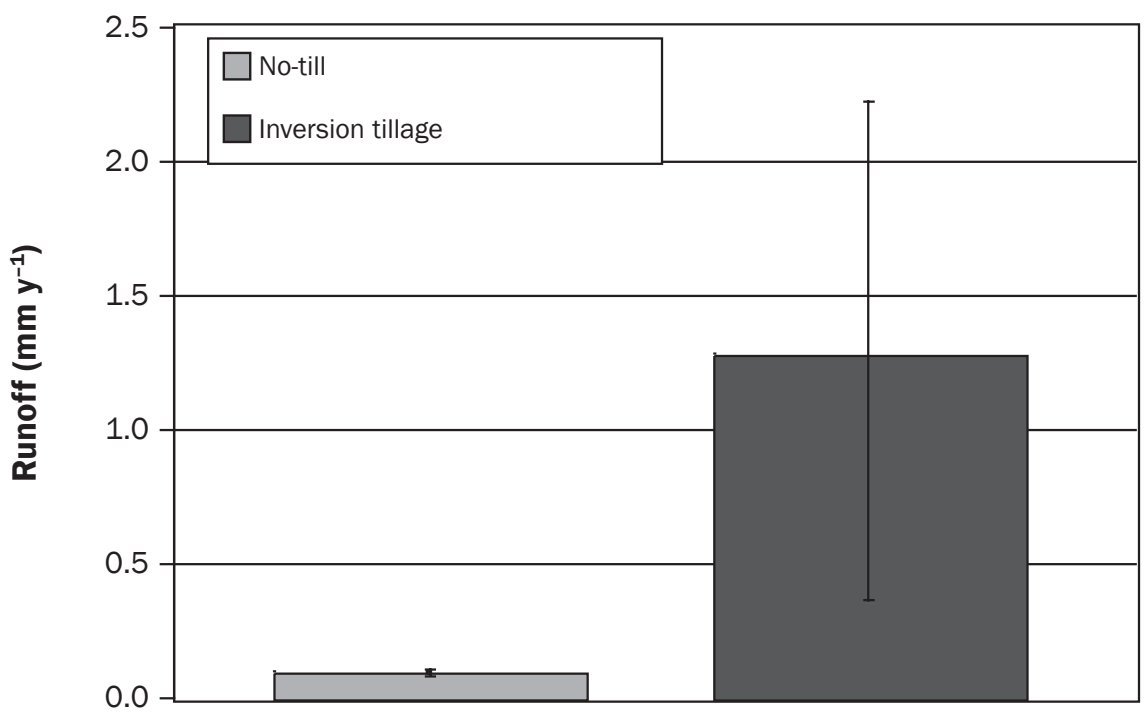

(b)

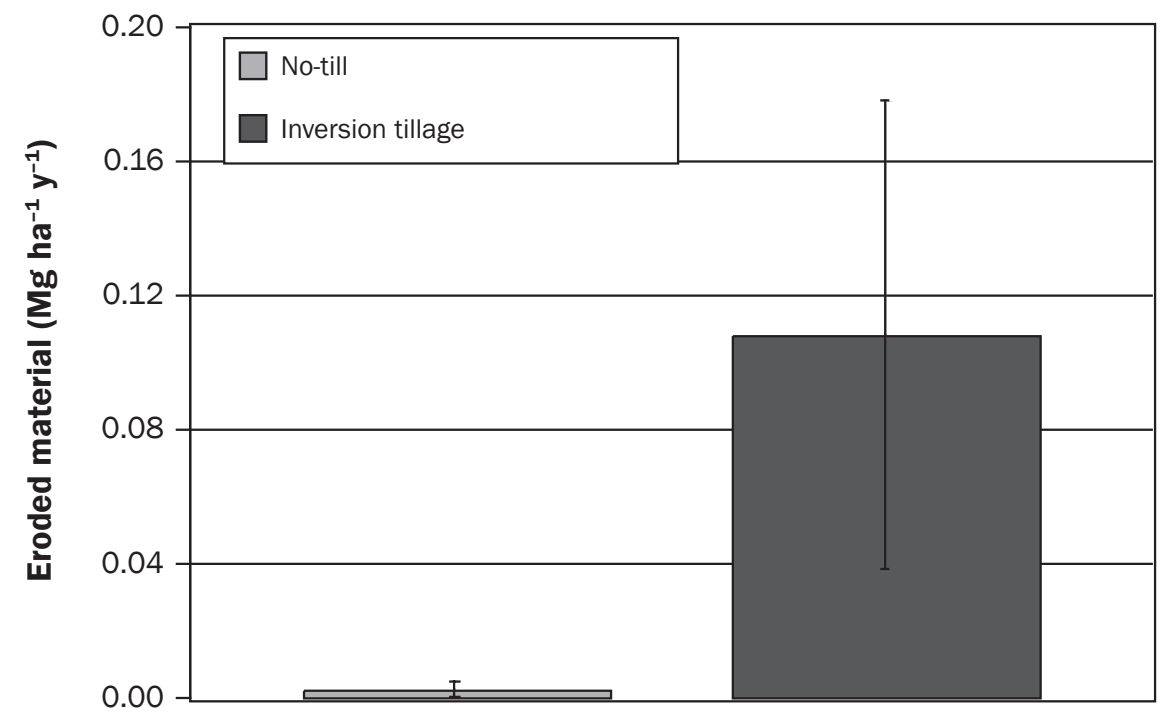

in climate, soils, topography, and crops produced, the relative difference in hydrologic response between no-till and inversion tillage that we report is not unusual.

Such comparisons, however, are hampered by differences in study duration, and the degree of replication of experimental treatments. The values reported Shipitalo and Edwards (1998) are based on replicated data collected from treatments that have been in place for over three decades and encompassed a range of meteorological events, whereas other studies took place over fairly short time frames (table 4). Our study was conducted during years with relatively few of the storms that cause the greatest amount of erosion in this region (Zuzel et al. 1986). Consequently, quantitative inferences that can be drawn from the results are limited. Nagle and Ritchie (2004) conducted a landscape-scale evaluation of soil erosion in the Wildhorse watershed, using ${ }^{137} \mathrm{Cs}$ and other nucleotides resulting from radioactive fallout. They reported rates of $2.48 \mathrm{Mg} \mathrm{ha}^{-1} \mathrm{y}^{-1}(1.11$ 


\section{Table 5}

Winter wheat yields in individual years with means for inversion tillage and no-till.

\begin{tabular}{|c|c|c|c|c|}
\hline Cropping system & $\begin{array}{l}2002 \\
\left(\mathrm{~kg} \mathrm{ha}^{-1}\right)\end{array}$ & $\begin{array}{l}2003 \\
\left(\mathrm{~kg} \mathrm{ha}^{-1}\right)\end{array}$ & $\begin{array}{l}2004 \\
\left(\mathrm{~kg} \mathrm{ha}^{-1}\right)\end{array}$ & $\begin{array}{l}\text { Mean yield } \\
\left(\mathrm{kg} \mathrm{ha}^{-1}\right)\end{array}$ \\
\hline \multicolumn{5}{|l|}{ Inversion tillage } \\
\hline Summer fallow-winter wheat & 4,341 & - & 5,220 & 4,780a† \\
\hline \multicolumn{5}{|l|}{ No-till } \\
\hline Chemical fallow-winter wheat & 3,874 & 3,466 & 5,815 & $4,385 a$ \\
\hline Chickpea-winter wheat & 1,130 & 3,026 & 5,272 & $3,143 a$ \\
\hline Mean yield & 3,115a† & $3,246 a$ & $5,436 a$ & \\
\hline
\end{tabular}

* Means followed by the same letter in a column are not significantly different at the $5 \%$ probability level.

$\dagger$ Means followed by the same letter in a row are not significantly different at the $5 \%$ probability level.

th $\mathrm{ac}^{-1} \mathrm{yr}^{-1}$ ) from a $5 \%$ slope in pasture since 1971, and $5.12 \mathrm{Mg} \mathrm{ha}^{-1} \mathrm{y}^{-1}\left(2.28 \mathrm{tn} \mathrm{ac}^{-1} \mathrm{yr}^{-1}\right)$ from a winter wheat-summer fallow field on a $5 \%$ slope. These values represent an integration of large and small soil erosion events that have occurred since atmospheric testing of nuclear weapons ended in 1963. The soil erosion rates we report exceed these values even though they result from a relatively mild meteorological period.

Crop Production/Field Yields. Dry autumns in 2002, 2003, and 2004 resulted in late seeding of the no-till winter wheat. Wheat yields in both systems were depressed as a result of the dry 2001 and 2002 winters and springs. Furthermore, lower than normal total spring precipitation contributed to very low chickpea production in those years. Mean yields of winter wheat increased with yearly rainfall, which were $258 \mathrm{~mm}$ (10.16 in), $351 \mathrm{~mm}$ (13.82 in), and $440 \mathrm{~mm}$ (17.32 in) in 2002, 2003, and 2004 (table 5). Mean yields of winter wheat by cropping system were $4,780 \mathrm{~kg} \mathrm{ha}^{-1}\left(71 \mathrm{bu} \mathrm{ac}^{-1}\right)$ following tilled summer fallow versus 4,385 $\mathrm{kg} \mathrm{ha} \mathrm{h}^{-1}$ (65 bu $\left.\mathrm{ac}^{-1}\right)$ following chemical fallow and $3,143 \mathrm{~kg} \mathrm{ha}^{-1}\left(47 \mathrm{bu} \mathrm{ac}^{-1}\right)$ following chickpea and winter wheat under no-till. Unfortunately, we cannot demonstrate a significant difference in yield between years or cropping systems. A small number of observations $(n \leq 3)$ gave us insufficient power to detect real and significant differences between treatments, but this does not rule out the possibility of the practical importance of these results (Altman and Bland 1995).

For example, winter wheat yields from summer fallow, inversion tillage appear to be greater than those from no-till cropping (table 5). Rasmussen et al. (1997) identified heavy residual straw levels, light quality, low soil temperatures, and pathogen activity as factors inhibiting winter wheat yields in no-till systems. Citing lack of sufficient seedzone soil water in late summer and early fall, Schillinger and Bolton (1992) found that no-till systems, which intrinsically maintain a system of connected micro- and macro-pores between the surface and soil in the root zone, lose moisture in the topsoil by capillarity and evaporation. In contrast, inversion tillage traps moisture in the seed zone by breaking capillary continuity between soil below $5 \mathrm{~cm}$ (2 in) and the soil surface. When adequate seed-zone moisture is available, it is possible to seed in late summer or early fall and have germination by early to mid-October. Wheat seeded this early has a competitive advantage against weeds, especially downy brome, and is developed sufficiently to take advantage of early spring warming and abundant soil water. Thus, no-till crops are generally seeded later, and in this experiment they were seeded each year between October 15 and 20, whereas the crop in the inversion tillage could be seeded in early October. In 2004, higher yields of winter wheat following chemical fallow and following chickpea-winter wheat compared with that following summer fallow (table 5) suggests that the limitations of no-till production systems in the inland PNW may be less pronounced in wet years.

Winter wheat recropped after chickpeas produced the lowest yield in the no-till production system (table 5), probably because of depleted soil water reserves. The purpose of the alternate crop-fallow system in semiarid regions is to replenish stored soil water and thus reduce the risk of crop failure. Therefore, one would not expect the grain yields of winter wheat to be normal under more intensive cropping, especially in a low precipitation year, such as 2002 .

\section{Summary and Conclusions}

Runoff and soil erosion from a conventional inversion tillage two-year winter wheat-fallow rotation system, and a no-till four-year winter wheat-chickpea-winter wheat-chemical fallow rotation system were compared in matched drainages located in northeastern Oregon. Virtually no runoff and soil erosion occurred within the no-till drainage compared to the inversion-tillage drainage. Soil erosion measured at the drainage scale in this research was a fraction of that reported for drainages with similar tillage systems in the PNW, other areas of the United States, and Brazil. Soil erosion in this study was lower than expected because of the relatively mild weather conditions during 2001 through 2004. Additionally, because of equipment failure and data loss, soil loss values for the inversion tillage are lower than the actual losses. Sample size in the controlled watershed experiment was inadequate for detecting a difference in the winter wheat yields between the systems, but from a practical standpoint, average winter wheat yields from the no-till fallow system were less than from the conventional tillage fallow system. Additional studies are needed to definitively address the yield potential of the two systems. Nevertheless, the results of this study demonstrate that no-till systems in the semiarid wheat producing region of interior Oregon and Washington may provide substantial soil and water conservation benefits.

\section{Acknowledgements}

Clinton Reeder, owner/operator of Reeder Farms, Helix, Oregon, provided the land used in this research. The authors would like to thank Dave Robertson, Scott Oviatt, Daryl Haasch, Don Hulick, Bob Correa, Amy Baker, Chris Roager, Felicity Dye, Kevin Collins, and college interns Gretchen Deutschlander and Eric Boyle for technical assistance.

\section{Disclaimer}

Use of manufacturer name does not constitute endorsement of product by the USDA.

\section{References}

Altman, D.G., and J.M. Bland. 1995. Absence of evidence is not evidence of absence. British Medical Journal 311(7003): 485 .

Angle, J.S., G. McClung, M.S. McIntosh, P.M. Thomas, and D.C. Wolf. 1984. Nutrient losses in runoff from conventional and no-till corn watersheds. Journal of Environmental Quality 13(3):431-435.

Bissett, M.J., and G.J. O'Leary. 1996. Effects of conservation tillage and rotation on water infiltration in two soils in south-eastern Australia. Australian Journal of Soil Research 34(2):299-308 
Brown, B., J.D. Istok, R.W. Katz, and A.H. Murphy. 1983. Statistical analysis of climatological data to characterize erosion potential. 2. Precipitation events in eastern Oregon/Washington. Special Report 687. Corvallis, OR: Oregon State University Extension Service.

Bubenzer, G.D., M. Molnau, and D.K. McCool. 1985. Low intensity rainfall with a rotating disk simulator. Transactions of American Society of Agricultural Engineers 28(4):1230-1232.

Cambardella, C.A., and E.T. Elliott. 1993. Carbon and nitrogen distribution in aggregates from cultivated and native grassland soils. Soil Science Society of America Journal 57(4):1071-1076.

Castro, N.M. dos R., A.V. Auzet, P. Chevallier, and J.C. Leprun. 1999. Land use change effects on runoff and erosion from plot to catchment scale on the basaltic plateau of Southern Brazil. Hydrological Processes 13(11):1621-1628.

Dickey, E.C., C.R. Fenster, R.H. Mickelson, and J.M. Laflen. 1984. Tillage and erosion in a wheat-fallow rotation. Publication of the Great Plains Agricultural Council Bozeman, MT. Montana State University Cooperative Extension Service.

Edwards, W.M., G.B. Triplett, D.M. Van Doren, L.B. Owens, C.E. Redmond, and W.A. Dick. 1993. Tillage studies with a corn-soybean rotation: Hydrology and sediment loss. Soil Science Society America Journal 57(4):1051-1055.

Floyd, D.A., and J.E. Anderson. 1982. A new point interception frame for estimating cover vegetation. Vegetatio 50(3):185-186.

Fritz, K.M., B.R. Johnson, and D.M. Walters. 2006. Field Operations Manual for Assessing the Hydrologic Permanence and Ecological Condition of Headwater Streams. EPA/600/R-06/126. Washington DC: Office of Research and Development, US Environmental Protection Agency.

Glysson, G.D., and J.R. Grays. 2002. Total suspended solids data for use in sediment studies. In Proceedings of Turbidity and Other Sediment Surrogates Workshop, April 30-May 2, 2002, Reno, NV.

Hurlbert, S.H. 1984. Pseudoreplication and the design of ecological field experiments. Ecological Monographs 54(2):187-211.

Johnson, D.R., and A.J. Makinson. 1988. Soil Survey of Umatilla County Area, Oregon. Washington, DC: USDA-Soil Conservation Service, US Government Printing Office.

Khalid, A.M., and S. Chen. 2003. The effect of frozen soil depth on winter infiltration hydrology in the Pataha Creek watershed. Paper No. 032160. St. Joseph, MI: American Society of Agricultural Engineers.

McCool, D.K., R.I. Papendick, and J.E. Hammel. 1995. Surface residue management. In Crop Residue Management to Reduce Erosion and Improve Soil Quality, ed. R.I. Papendick, and W.C. Moldenhauer, 10-16. Conservation Report Number 40. USDA Agricultural Research Service.

McGregor, A.C. 1982. Counting Sheep: From Open Range to Agribusiness on the Columbia Plateau. Seattle, WA: University of Washington Press.

McGregor, K.C., and J.D. Greer. 1982. Erosion control with no-till corn for silage and grain. Journal of Environmental Quality 25(1):154-159.

Nagle, G.N., and J.C. Ritchie. 2004. Wheat field erosion rates and channel bottom sediment sources in an intensively cropped Northeastern Oregon drainage basin. Land Degradation and Development 15(1):15-26.
Oviatt, H.S., and D.E. Wilkins. 2002. USDA-ARS meteorological monitoring in northeastern Oregon. In Columbian Basin Agricultural Research Special Report 1040, ed. A. Bechtel, and H.S. Oviatt, 15-25. Pendleton, OR: Oregon State University Agricultural Experiment Station.

Rasmussen, P.E., R.W. Rickman, and B.L. Klepper. 1997. Residue and fertility effects on yield of no-till wheat. Agronomy Journal 89(4):563-567.

Renard, K.G., G.R. Foster, G.A. Weesies, D.K. McCool, and D.C. Yoder (coordinators). 1997. Predicting Soil Erosion by Water: A Guide of Conservation Planning with the Revised Universal Soil Loss Equation (RUSLE). USDA Agriculture Handbook No. 703. Washington, DC: USDA.

Schillinger, W.F., and F.E. Bolton. 1992. Summer fallow water storage of no-till versus conventional tillage in the Pacific Northwest. In Columbia Basin Agricultural Research Special Report 894, ed. T. Chastain, 28-31. Pendleton, OR: Oregon State University Agricultural Experiment Station.

Shipitalo, M.J., and W.M. Edwards. 1998. Runoff and erosion control with conservation tillage and reducedinput practices on cropped watersheds. Soil and Tillage Research 46(1-2):1-12.

Six, J., E.T. Elliott, and K. Paustian. 2000. Soil macroaggregate turnover and microaggregate formation: A mechanism for $\mathrm{C}$ sequestration under no-tillage agriculture. Soil Biology and Biochemistry 32(14):2009-2103.

Smiley, R.W. 1992. Estimate of cultivated acres for agronomic zones in the Pacific Northwest. In Columbia Basin Agricultural Research Special Report 894, ed. T. Chastain, 86-87. Pendleton, OR: Oregon State University Agricultural Experiment Station.

US Department of the Interior. 2001. Chapter 8, Flumes; 10. Parshall flumes. In Water Measurement Manual. US Government Printing Office stock number 024-00300180-5. Washington, DC: Bureau of Reclamation, US Department of the Interior. http://www.usbr. gov/pmts/hydraulics_lab/pubs/wmm/chap08_10.html.

Zuzel, J.F., R.R. Allmaras, and R. Greenwalt. 1982. Runoff and soil erosion on frozen soils in northeastern Oregon. Journal Soil and Water Conservation 37(6):351-354.

Zuzel, J.F., and J.L. Pikul Jr. 1987. Infiltration into a seasonably frozen agricultural soil. Journal Soil and Water Conservation 42(6):447-450.

Zuzel, J.F., and J.L. Pikul Jr. 1993. Effects of straw mulch on runoff and erosion from small agricultural plots in northeastern Oregon. Soil Science 156(2):111-117.

Zuzel, J.F., J.L. Pikul Jr., and R.N. Greenwalt. 1986. Point probability distributions of frozen soil. Journal of Climate and Applied Meteorology 25(11):1681-1686. 